\title{
Varietal Screening of Newly Evolved Chilli Hybrid Camparing with Traditional Varieties against Thrips (Scirtothrips dorsalis Hood.) and White Fly (Bemisia tabaci Genn.)
}

\author{
Bhavna Verma $^{1 *}$ and Sanjay Vaishampayan ${ }^{2}$ \\ ${ }^{1}$ Dr. B. R. Ambedkar University of Social Sciences, Mhow Indore (MP), India \\ ${ }^{2}$ D.E.S. JNKVV Jabalpur (M.P.), India \\ *Corresponding author
}

A B S T R A C T

K e y w o r d s
Chilli, Thrips,
$\begin{aligned} & \text { White fly, } \\ & \text { Varietal screening, } \\ & \text { Population }\end{aligned}$
Article Info
$\begin{aligned} & \text { Accepted: } \\ & \text { 04 September } 2020 \\ & \text { Available Online: } \\ & \text { 10 October } 2020\end{aligned}$

Introduction

Chilli (Capsicum annuum L.) is an important vegetable cum spice crop grown in almost all parts of tropical and subtropical regions of the world. It requires a warm humid climate. It belongs to the family Solanaceae and originated from South and Central America Chilli is represents a diverse plant group. The name is derived from Latin word "Capsa" that means "hallow pod". Chilli is historically associated with the voyage of Columbus, who on his first voyage encountered a plant whose fruits mimicked the pungency of the black
Investigations on Varietal screening of newly evolved chilli hybrid camparing with traditional varieties against thrips (Scirtothrips dorsalis Hood.) and white fly (Bemisia tabaci Genn.) were carried out at Samajik Vigyan Kendra, Dr. B. R. Ambedkar University Rehti, (Village Bordi) Tehsil- Nasrullaganj, Distt- Sehore (M.P.) during Rabi, 2018-19 and 2019-20. Out of ten varieties of chilli screened against major sucking pests none of the variety was found completely free from the attack of white fly. The varieties, VNR-277 \& VNR-577 were ranked as least susceptible, while Pusa Jawala and US-1003 as highly susceptible and US- 9009, MHCP-310, MHCP-317, US-7030, VNR-1921, and VNR-109 as moderately susceptible. The maximum fruit yield of chilli was also obtained in the variety VNR-277 followed by VNR-577 and US-9009 and minimum was in Pusa Jawala and US-1003.

pepper, he called it red pepper because of the red pod colour

The fruits are an essential spice and condiments in the Indian home known for its pungency and are used in its raw-green, ripe and dry stages. It is rich in vitamins especially vitamin $\mathrm{A}$ and $\mathrm{C}$ and $\mathrm{E}$ widely used for the manufacture of curry powder and preparation of sauces, soup, salad, ketchup etc. It imparts delicious taste and pleasant flavour to the cuisine. Capsanthin, a pigment in chilli used for natural colouration to jam, jellies and squashes. Since, it is natural pigment and 
having no harmful or side effect on human health. Out of total production of chillies 9095 per cent consumed within the country and about 5-10 per cent exported in the form of dry chilli, chilli powder and oleoresins (Singhal, 2003). India is the world's largest producer of chilli and the crop is grown all over the country, occupies an area of 775 thousand ha with a production of 1492 thousand tones.

India contributes about $36 \%$ to the total world production. In India Andhra Pradesh is the largest producer of chilli and contributes about $26 \%$ to the total area under chilli followed by Maharashtra (15\%), Karnataka (11\%), Orissa (11\%), Madhya Pradesh (7\%) and other states contributing nearly $22 \%$ to the total area under chilli. In Madhya Pradesh, chilli occupies an area of 54410 ha with a production of 93570 MT of chilli (Anonymous, 2015). Although, the crop has got great export potential besides huge domestic requirement, a number of limiting factors have been attributed for low productivity.

Among them occurrence of viral diseases as well as ravages caused by insect pests are significant ones. The pest spectrum of chilli crop is complex with more than 293 insects and mite species debilitating the crop in the field as well as in storage (Anonymous.1987 and Dey et al., 2001). In india nearly 25 insects have been recorded attacking chilli leaves and fruits, Among the plethora of constraints in chilli cultivation, the attack by a multitude of insect pests and mites at different crop stages is of utmost concern. One of the practical means of increasing chilli production is to minimize losses caused by major sucking pests, the most important among them are green peach aphid (Myzus persicae Sulzer, Aphis gossypi Glover), thrips (Scirtothrips dorsalis Hood) and yellow mite (Polyphagotarsonemus latus Banks) whitefly
(Bemicia tabaci Gennadius) and leafhoppers (Amrasca biguttula biguttula Ishida) (Berke and Sheih, 2000). Besides, a number of viruses are transmitted by aphids, white flies etc which result into a complex murda (Gundannavar et al., 2007).

\section{Materials and Methods}

The experiment was laid out in a Randomized Block Design (RBD). Ten chilli varieties viz., VNR-577, VNR-109, VNR-277, VNR-1921, US-1003, US-9009, US-7030, MHCP-310, MHCP-317, and Pusa jwala were screened for their relative susceptibility to thrips and white fly each replicated thrice. The plot size was $2 \mathrm{X} 2 \mathrm{~m}^{2}$ keeping row to row and plant to plant distance of $0.5 \mathrm{~m}$. and $45 \mathrm{~cm}$. respectively. The recommended packages of practices except pesticide application were followed to raise the crop.

\section{Observation to be recorded}

The population of nymphs and adults of thrips and whitefly was recorded on three leaves of chilli at top, middle and bottom canopy from five randomly selected and tagged plants in each plot at weekly interval from the appearance to last picking of the chilli fruits. The population was counted visually using a magnifying lens in early morning hours (Bhede et al., 2008).

\section{Results and Discussion}

\section{Thrips, Scirtothrips dorsalis Hood}

The data presented in table 1 showed that none of the chilli varieties screened against thrips was observed to be completely free from the attack of thrips the mean population of thrips at all the intervals ranged from 6.61 to $12.87,7.37$ to 15.10 and 6.99 to 13.99 per three leaves during 2018-19, 2019-20 and pooled, respectively. 
The minimum population was observed in VNR-277 (6.61, 7.37 and 6.99/three leaves), followed by VNR-577 (6.93, 7.67 and $7.30 /$ three leaves) however, these varieties were statistically at par to each other. The maximum population was recorded on Pusa Jawala (12.87, 15.10 and 13.99/three leaves), followed by US-1003 (12.22, 14.30 and 13.26/three leaves), and both were at par with each other. The rest of the varieties, viz., US9009, MHCP-310, MHCP-317, US-7030, VNR-1921, VNR-109 registered thrips population of 10.12 to $12.00,9.59$ to 12.06 and 9.86 to 12.03 per three leaves, respectively during 2018-19, 2019-20 and pooled were grouped as moderately susceptible and stood at par with each other in their degree of infestation.

However, the variety Pusa Jawala and US1003 were also on par with VNR-109 and VNR-1921 of middle order. Based on mean data the variety VNR-277 and VNR-577 were least susceptible; while US-9009, MHCP-310, MHCP-317, US-7030, VNR-1921 and VNR109 were moderately susceptible and variety Pusa Jawala and US-1003 was highly susceptible.

Table.1 Varietal susceptibility of chilli against major sucking pests during Rabi, 2018-19, 2019-20 \& Pooled

\begin{tabular}{|c|c|c|c|c|c|c|c|c|c|c|}
\hline \multirow[t]{2}{*}{ S. N. } & \multirow[t]{2}{*}{ Varieties } & \multicolumn{3}{|c|}{ Thrips/3 leaves } & \multicolumn{3}{|c|}{ Whitefly/3 leaves } & \multicolumn{3}{|c|}{ Yield (q/ha) } \\
\hline & & 2018-19 & $2019-20$ & Pooled & 2018-19 & $2019-20$ & Pooled & 2018-19 & $2019-20$ & Pooled \\
\hline \multirow[t]{2}{*}{1.} & VNR-577 & 6.93 & 7.67 & 7.30 & 6.50 & 7.19 & 6.85 & 75.28 & 73.89 & 74.58 \\
\hline & & (2.78) & $(3.50)$ & (3.41) & (3.35) & (3.52) & $(3.44)$ & & & \\
\hline \multirow[t]{2}{*}{2.} & VNR-109 & 12.00 & 12.06 & 12.03 & 11.77 & 11.09 & 11.43 & 61.33 & 62.29 & 61.81 \\
\hline & & $(4.82)$ & (4.61) & $(4.72)$ & (4.46) & (4.35) & $(4.41)$ & & & \\
\hline \multirow[t]{2}{*}{3.} & VNR-277 & 6.61 & 7.37 & 6.99 & 6.30 & 7.18 & 6.74 & 78.67 & 76.55 & 77.61 \\
\hline & & $(3.23)$ & $(3.47)$ & (3.35) & (3.31) & $(3.51)$ & (3.41) & & & \\
\hline \multirow[t]{2}{*}{4.} & VNR-1921 & 10.84 & 10.99 & 10.92 & 10.79 & 10.72 & 10.76 & 63.57 & 64.53 & 64.05 \\
\hline & & (4.39) & (4.46) & (4.43) & (4.16) & (4.13) & (4.15) & & & \\
\hline \multirow[t]{2}{*}{5.} & US-1003 & 12.22 & 14.30 & 13.26 & 13.12 & 11.55 & 12.34 & 53.72 & 50.63 & 52.17 \\
\hline & & $(4.54)$ & (5.08) & (4.81) & $(4.84)$ & $(4.47)$ & (4.66) & & & \\
\hline \multirow[t]{2}{*}{6.} & US-9009 & 10.12 & 9.59 & 9.86 & 8.31 & 8.00 & 8.16 & 74.78 & 72.99 & 73.88 \\
\hline & & $(4.31)$ & (4.17) & (4.24) & (4.01) & (3.66) & (3.84) & & & \\
\hline \multirow[t]{2}{*}{7.} & US-7030 & 10.58 & 10.41 & 10.50 & 10.33 & 10.07 & 10.20 & 65.20 & 63.59 & 64.39 \\
\hline & & $(4.36)$ & (4.34) & (4.35) & (4.13) & (4.12) & (4.13) & & & \\
\hline \multirow[t]{2}{*}{8.} & МНСР-310 & 10.48 & 9.71 & 10.10 & 8.49 & 9.33 & 8.91 & 67.55 & 68.46 & 68.00 \\
\hline & & (4.15) & (4.25) & (4.20) & (3.75) & $(4.00)$ & (3.88) & & & \\
\hline \multirow[t]{2}{*}{9.} & МНСР-317 & 10.49 & 9.89 & 10.19 & 8.90 & 9.62 & 9.26 & 67.82 & 69.07 & 68.44 \\
\hline & & $(4.24)$ & (4.34) & (4.29) & (4.07) & $(4.06)$ & $(4.07)$ & & & \\
\hline \multirow[t]{5}{*}{10} & Pusa jwala & 12.87 & 15.10 & 13.99 & 13.24 & 12.48 & 12.89 & 51.70 & 50.08 & 50.89 \\
\hline & & $(4.88)$ & (5.23) & (5.06) & (4.76) & (4.68) & $(4.72)$ & & & \\
\hline & S Em \pm & 0.09 & 0.09 & 0.09 & 0.13 & 0.08 & 0.10 & 2.23 & 2.19 & 2.23 \\
\hline & $\mathrm{CD}$ at $5 \%$ & 0.27 & 0.28 & 0.28 & 0.28 & 0.25 & 0.28 & 6.47 & 6.38 & 6.47 \\
\hline & $\mathrm{CV} \%$ & 8.35 & 8.81 & 8.59 & 8.82 & 8.06 & 8.71 & & & \\
\hline
\end{tabular}

Mean of three replications

Figures in the parentheses are $\sqrt{\mathrm{X}+0.5}$ values

Peak population of whitefly 
The present results conform with those of Panickar and Patel (2001) observed chilly cultivar ACS-92-4 and G-4 as less susceptible to thrips and Pusa Jawala and S-49 as most susceptible however, both proved to be have higher yield potential. Likewise, Tatagar et al., (2001) identified chilli cultivars Pant C-1, LCA-304 and LCA- 312 as promising source of resistance against thrips and mites support the present findings. Kalaiyarasan et al., (2002) reported lower infestation of thrips was in the variety PS-64. Singh and Singh (2009) recorded lower thrips population on chilly cultivars, G-4 and Chanchal than local cultivar AM-1 and Pusa Jawala, however both showed high yield potential under high pressure of pest.

\section{Whitefly, Bemisia tabaci Genn.}

The data presented in table 1 showed that none of the chilli varieties screened against thrips was observed to be completely free from the attack of thrips the mean population of thrips at all the intervals ranged from 6.30 to $13.24,7.18$ to 12.48 and 6.74 to 12.89 per three leaves during 2018-1-, 2019-20 and pooled, respectively.

The minimum population was observed in VNR-277 (6.30, 7.18 and 6.74/three leaves), followed by VNR-577 (6.50, 7.19 and $6.85 /$ three leaves) however, these varieties were statistically at par to each other. The maximum population was recorded on Pusa Jawala (13.24, 12.48 and 12.89/three leaves), followed by US-1003 (13.12, 11.55 and $12.34 /$ three leaves), and both were stood at par with each other. The rest of the varieties, viz., US-9009, MHCP-310, MHCP-317, US7030, VNR-1921, VNR-109 registered thrips population of 8.31 to $11.77,8.00$ to 11.09 and 8.16 to 11.43 per three leaves, respectively during 2018-19, 2019-20 and pooled were grouped as moderately susceptible and stood at par with each other in their degree of infestation. However, the variety Pusa Jawala and US-1003 were also on par with VNR-109 and VNR-1921 of middle order. Based on mean data the variety VNR-277 and VNR577 were least susceptible; while US-9009, MHCP-310, MHCP-317, US-7030, VNR1921 and VNR-109 were moderately susceptible and variety Pusa Jawala and US1003 was highly susceptible.

Yield performance of different chilli varieties

The data presented in table 1 revealed that maximum fruit yield of 78.67, 76.55 and $77.61 \mathrm{q}$ ha-1 was obtained in variety VNR277, followed by VNR-577 (75.28, 73.89 and $74.58 \mathrm{q}$ ha-1) and US-9009 (74.78, 72.99 and 73.88 q ha-1) during 2018-19, 2019-20 and pooled basis, respectively however, these were at par and significantly superior to other varieties. The minimum fruit yield was obtained in the variety Pusa Jawala (51.70, 50.08 and 50.89 q ha-1) and US-1003 (53.72, 50.63 and $52.17 \mathrm{q}$ ha-1) and both were at par with each other and significantly inferior to rest of the varieties. The yield obtained in rest of the varieties viz., MHCP-310 (67.55, 68.46 and $68.00 \mathrm{q}$ ha-1), MHCP-317 (67.82, 69.07 and $68.44 \mathrm{q}$ ha-1), US-7030 (65.20, 63.59 and 64.39 q ha-1), VNR-1921 (63.57, 64.53 and $64.35 \mathrm{q}$ ha-1) and VNR-109 (61.33, 62.29 and 61.81 q ha-1) during 2018-19, 2019-20 and pooled basis, respectively and these were comparable with each other. Based on fruit yield the descending order of chilli varieties were VNR-277 > VNR-577 > US-9009> MHCP-310 > MHCP-317 > US-7030 > VNR1921 > VNR-109 > US-1003 > Pusa Jawala.

In conclusion the present investigation was undertaken screening of chilli varieties against major sucking pests, none of them was found completely free from the attack of pests. The varieties VNR-277 and VNR-577 were categorized as least susceptible while, 
Pusa Jawala and US-1003 as highly susceptible to thrips and whitefly. The maximum fruit yield was also recorded in variety VNR-277 followed by VNR-577 and US-9009.

\section{Acknowledgement}

The research findings are the part of the research work of Ph.D. Programme of the first author to be submitted to the Department of Agricultural Entomology, Dr. B. R. Ambedkar University of Social Sciences Mhow Indore (M.P.) We are very grateful to Dr. Sanjay Vaishampayan (Senior Scientist at D.E.S. JNKVV Jabalpur) to have helped a lot in the research work, field monitoring and data collection.

\section{References}

Anonymous, 1987. Progress Report 1987 for Asian Vegetable Research and Development centre, Taiwan. pp 77 99.

Anonymous (2015). Indian Horticulture Database. PP: 6-7 \& 285.

Dey P.K., Sarkar P.K. and Somchoudhury A.K. (2001). Efficacy of different treatment schedules of profenofos against major pest of chilli. Pestol., 25 (11):26-29.

Berke, T. and Sheih, S. C. (2000). Chilli peppers in Asia. Capsicum and Egg Plant Newsletter, 19: 38-41.

Bhede BV, Suryawanshi DS, More DG. Population dynamics and bioefficacy of newer insecticide against chilli thrips, Scirtothrips dorsalis (Hood). Indian Journal of Entomology. 2008; 70(3):223-226.

Gundannavar, K. P. Giraddi, R. S. Kulkarni, K. A. and Awaknavar, J. S. (2007). Development of integrated pest management modules for chilli pests. Karnataka Journal Agriculture Science, 20(4): 757-760.

Kalaiyarasan S, Sathiyannantham VRK, Geetha C, Muthusamy M. Screening of different chilli accessions against thrips, Scirtothrips dorsalis Hood. South Indian Horticulture. 2002; 50(4/6):613-615.

Panickar BK, Patel JR. Susceptibility of some of the genotypes/ cultivars of chilli to thrips, Scirtothrips dorsalis Hood. Indian Journal of Entomology. 2001; 63(1): 52-54.

Singh DK, Singh Kumar S. Susceptibility of chilli cultivars to thrips, Scirtothrips dorsalis Hood. Annals of Horticulture. 2009; 2(1): 126-127.

Singhal, V. (2003). Chilies- In Indian Agriculture 2003, Indian Economic Data Research Centre, Mayapuri, New Delhi, pp. 565-570.

Tatagar MH, Prabhu ST, Jagadeesha RC. Screening chilli genotypes for resistance to thrips, Scirtothrips dorsalis Hood and mite, Polyphagotarsonemus latus (Banks). Pest Management in Horticultural Ecosystems. 2001; 7(2): 113-116.

\section{How to cite this article:}

Bhavna Verma and Sanjay Vaishampayan. 2020. Varietal Screening of Newly Evolved Chilli Hybrid Camparing with Traditional Varieties against Thrips (Scirtothrips dorsalis Hood.) and White Fly (Bemisia tabaci Genn.). Int.J.Curr.Microbiol.App.Sci. 9(10): 189-193. doi: https://doi.org/10.20546/ijcmas.2020.910.024 